\author{
A.Zh. Baiguzhinova ${ }^{1}$, L. Tyll $^{2}$ \\ ${ }^{\text {I} N a r x o z ~ U n i v e r s i t y, ~ K a z a k h s t a n ~}$ \\ ${ }^{2}$ University of Economics, Prague, Czech Republic \\ lalma.baiguzhinova@narxoz.kz, ${ }^{2}$ ladislav.tyll@vse.cz \\ ${ }^{1}$ https://orcid.org/0000-0002-3414-2213, ${ }^{2}$ https://orcid.org/0000-0002-4735-4776
}

\title{
Economic and statistical analysis of the dairy industry development in the Republic of Kazakhstan
}

\begin{abstract}
Object: The article examines the main factors affecting milk production and dairy products in Kazakhstan in the current competitive environment.

Methods: The article uses quantitative data, mathematic-statistical methods of studying connections (correlationregression analysis).

Findings: This study focuses on the dairy industry of Kazakhstan and its specificities. We have calculated the factors affecting the production of milk and dairy products using regression analysis using the example of the dairy industry of the Republic of Kazakhstan. The regression analysis showed that investment in fixed assets has a positive impact on the performance of this industry and is statistically significant. The results obtained can be used to study the influence of factors on the dairy enterprise production activities at any level and different ownership forms.

Conclusions: The article examined the key factors affecting the dairy industry in Kazakhstan. It also suggested priority necessary measures to improve the current development level of the dairy industry.
\end{abstract}

Keywords: dairy industry; milk and dairy production; trends and prospects for dairy industry.

\section{Introduction}

The economic potential of the country is the aggregate ability of the region's economy, its branches, enterprises, farms to carry out production and economic activities, produce high-quality products, goods, services that meet social needs, ensure the development of production and consumption. Based on this definition, the economic potential of a region depends on the availability of its natural resources, means of production, labor resources, scientific and technical potential, accumulated national wealth, the level of development of international relations. The economic potential can also be determined by the aggregate of the region's economic sectors, enterprises, institutions producing industrial, agricultural, construction products and providing various services for industrial and non-productive purposes. This principle is the basis for classifying the country's economic potential by area of activity. National food security depends on the accumulated economic potential of the aggregate of sectors and economic entities of the agro-industrial complex. One of the main branches of the agro-industrial complex is the dairy subcomplex, whose enterprises produce a wide range of products to meet the needs of the population.

The global dairy market is expected to grow significantly during the forecast period. Growing global population, rising per capita incomes, increased consumer awareness of the nutritional value of dairy products and changing consumer dietary patterns are key drivers of market growth. Besides, technological advances and innovations to obtain more milk from dairy animals are also estimated to contribute to market growth. Moreover, the dairy sector in most countries is complex, so clearcut strategies and interventions cannot be easily identified. No single strategy framework can be designed that fits the dairy sector in every country. Dairy production provides many non-marketed economic benefits, including manure for use onfarm as fuel or organic fertilizer (in several farming systems manure is the sole source of nutrients for crop production). Dairy animals are considered a means of safeguarding savings for sale in times of need (e.g., injury or disease of a household member), and a form of capital investment. However, there is the risk that dairy animals are stolen or die.

Increased adoption of sedentary lifestyles, unhealthy eating habits, and increased food awareness are also expected to increase market demand. Major milk and dairy producers have introduced new products with improved quality and nutritional value to meet growing market demand. These products include skimmed milk, low-fat energy drinks, and seasonal fruit yogurts (David et al., 2013). 


\section{Literature Review}

The food industry has been changing and evolving over the decades to meet customer needs and consumer behavior. This industry is characterized by a complex system of activities related to the supply, consumption, and delivery of food products around the globe. The global dairy industry, as its component, in turn, consists of many countries with unique production practices and consumer markets. Milk production is unique as an agricultural product because milk is produced daily and all year round. Dairy production is important to the economic development and sustainable development of communities in rural areas and the country as a whole. However, the necessary investment and the availability of local markets and labor is a constant challenge.

In the case of milk, we can identify four main causes of milk consumption. The first motive is its nutritional composition. In the population, milk is considered one of the most nutritious and balanced foods, «containing a wide range of essential nutrients needed for growth, development, and overall health and wellbeing throughout the life cycle» (The National Dairy Council, 2008, 65; The Dairy Council, 2014, 2015). The second one is a positive effect on health and the prevention of various diseases, such as the pleasant effects of milk consumption on the prevention of osteoporosis, lowering blood pressure and reducing the incidence of breast cancer, improving skin quality and texture (Dallmeier, 2012). The last two possible motives that may attract our local consumers to purchase dairy products such as milk are interrelated - tradition and breadth of use.

To date, the most popular type of milk is cow's milk, which accounts for $98 \%$ of Kazakhstan's milk consumption. This long-standing tradition has left its mark on our culture and especially in Kazakh national gastronomy. Several research and development activities have been carried out in the area of research and studies on the motivations for buying and consuming milk. They showed that the main reasons consumers bought milk tasted, healthy lifestyle, habit, availability of the product, and its use in the household (Saktaeva, 2010). A group of researchers (Alwis et al., 2009) analyzed factors affecting fresh milk consumption among consumers in Sri Lanka in 2009 and found that taste and nutritional value have a positive (stimulating) effect and vice versa, health problems, price levels, and product availability have a negative (scattering) effect on consumer decisions to buy fresh milk. Similar motives to those already mentioned came from other authors who identified taste, health, and price as the most important motives for choosing dairy drinks (Krešiü et al., 2010). However, there are also some discouraging factors that, conversely, create barriers to milk consumption and purchase. Consumers may be affected by some notes and articles in the media that present negative effects of milk consumption: excessive sputum formation, acne formation, digestive problems, lactose intolerance, allergies, or various other health problems caused by milk (Furindová, 2010). Nevertheless, all these negative views are now increasingly refuted by official statements of domestic and foreign doctors, nutritionists, and other experts in this field (Dairy Council of California, 2015).

\section{Methods}

The following scientific methods were used in the study: the deduction method used to perceive the problems of the economic potential and determine the methods for assessing its level; analysis method for assessing the production of dairy products in Kazakhstan and identifying factors and reasons for changing its level; the synthesis method used to obtain generalized research results, to formulate conclusions and general conclusions on the diagnosis of the current state of the economic potential of the dairy industry; comparison method used to justify the main direction of growth and effective use of the economic potential of the dairy subcomplex of the agricultural sector.

\section{Results}

The dairy industry is also considered one of the main industries providing a huge number of jobs around the world. According to FAOSTAT, the Food and Agriculture Organization Corporate Statistical Database, about 150 million households worldwide are involved in the production of milk and dairy products. Over the past three decades, total milk production has increased by more than $50 \%$, from 482 million tonnes to 754 million tonnes.

World milk production ( $81 \%$ of cow's milk, $15 \%$ of buffalo milk and $4 \%$ of other milk) increased by $1.6 \%$ in 2018 to 838 million tonnes. India has the largest milk producer in the world, with production increasing by $3.0 \%$ to 174 million tonnes, although this was a minor impact on the global dairy market as India trades only small quantities of milk and dairy products (OECD/FAO, 2019).

The three main dairy exporters achieved increased production in 2018, the European Union (0.8 percent), New Zealand (3.2 percent) and the United States (1.1 percent), which were almost entirely driven by 
higher yields per cow; in New Zealand, the favorable grass environment also played a role. As a result, the availability of fresh dairy products and processed products for export has increased. In the People's Republic of China, the world's largest importer of dairy products, milk production increased for the first time in four years by $1.1 \%$ in 2018. Official data on milk production in China were revised downward at the end of 2018 to $15 \%$ over the last ten years.

According to statistics from the UN Food and Agriculture Organization (FAO), India and Pakistan, important milk producers, are expected to contribute more than half the growth in world milk production over the next ten years, as well as more than $30 \%$ of world production in 2028. Production in the second largest milk producer, the European Union, is projected to grow more slowly than the world average as only a small proportion of production is exported and domestic demand grows slightly.

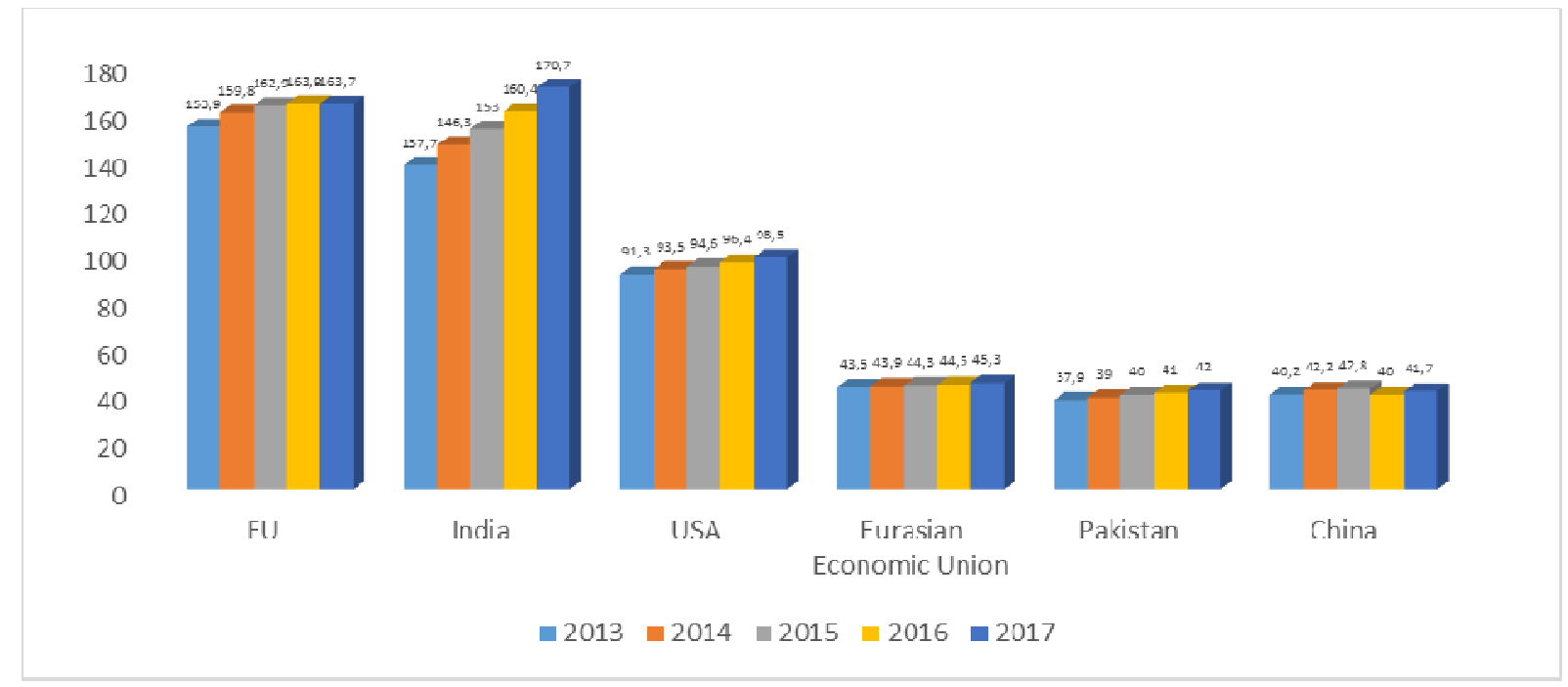

Figure 1. Dynamics of milk production in the world, million tons

Note - OECD/FAO (2019), “OECD-FAO Agricultural Outlook”, OECD Agriculture statistics (database) http://dx.doi.org/10.1787/agr-outl-data-en.

Asia and the Pacific are expected to be one of the fastest-growing regions for the forecast period. India accounts for about 20 percent of world dairy production. Population growth, high consumption of dairy products and accelerated economic growth in the region are factors contributing to significant growth (Nguyen, Hien, 2016).

In modern conditions, the production of dairy products takes a leading place in the agricultural sector of Kazakhstan. Today, the most popular type of milk is cow's milk (which accounts for 95-98\% of Kazakhstan's milk consumption). Such a long tradition has left consequences in our culture and especially in Kazakh national gastronomy. This can be proved by the fact that one of the main ingredients from which most Kazakh national dishes are made is milk and its products. Several research and development activities have been carried out in the area of studying and studying the motives for buying and consuming milk. Many authors have shown that the main reasons of purchase of milk by our consumers were taste, healthy way of life, habit, availability of the product and its use in the household (Khassenova et al, 2020; Taipov, 2018).

For Kazakhstan's dairy producers, operating in a market environment has been fraught with serious problems and significant risks. Even though agrarian sector traditionally played a significant role in the development of national economy, and thus, the development of dairy products industry, at first glance, should be brought at least a decent raw material base, the producers and analysts themselves state the slowdown in the growth of the industry and anxiously talk about the onset of imports. At the same time, the prices of dairy products can hardly be called democratic, and some consumers, who are not in the category of the affluent, today not every day can pamper themselves with buying curd or cheese, for example. Meanwhile, dairy consumption has a direct impact on the health of the nation and reflects the welfare of society. While in the first half of the prosperous 1980s, Kazakhstan's citizens consumed up to 600 tonnes of dairy products daily, during the crisis of the 1990s this figure dropped to 125 tonnes per day. The current world crisis has naturally affected the dairy products market, but analysts believe that in the coming years their consumption will not decline, but will increase. As for today, the production of milk and dairy products in the country is 
one of the most promising areas of development in the agricultural sector. The dairy industry, which includes cheese and dairy subbranches, as well as the production of whole milk products, at the present stage is one of the leading in the structure of the food industry of Kazakhstan.

Despite in-depth research, today many problems in the production of milk and dairy products in Kazakhstan remain unresolved and require in-depth study. The purpose of the article is to study the current state of the milk and dairy products market in Kazakhstan, identify the main problems and trends in its development.

Today, milk production has become an integral part of national food security and support for socially vulnerable groups, as well as a major source of welfare and employment for rural residents.

At present, there are 148 milk processing enterprises in Kazakhstan, whose production capacity allows processing about 1.9 million tons of milk per year (34 enterprises produce cheese). The leader in dairy production in the Kazakhstan market is FoodMaster Company JSC. Since 2004, FoodMaster has been part of the international group Lactalis (France). It has two own dairy farms and 16 trading branches. All FoodMaster enterprises are high-tech dairy plants producing products that meet the general quality standards of the company.

The current state of milk production in Kazakhstan is accompanied by negative trends in comparison with other agrarian developed countries. The development of the milk processing industry is significantly affected by the situation in dairy cattle breeding. Gasoline and diesel fuel prices rise, underdeveloped harvesting networks in rural areas, the remoteness of raw material zones from processing centers. As a result, the processors found themselves in a difficult financial situation. Although, according to the Committee on Statistics of Kazakhstan, all key industry indicators, such as cattle numbers, milk production and consumption per capita on average, have been growing up since 2014 (Figure 2).

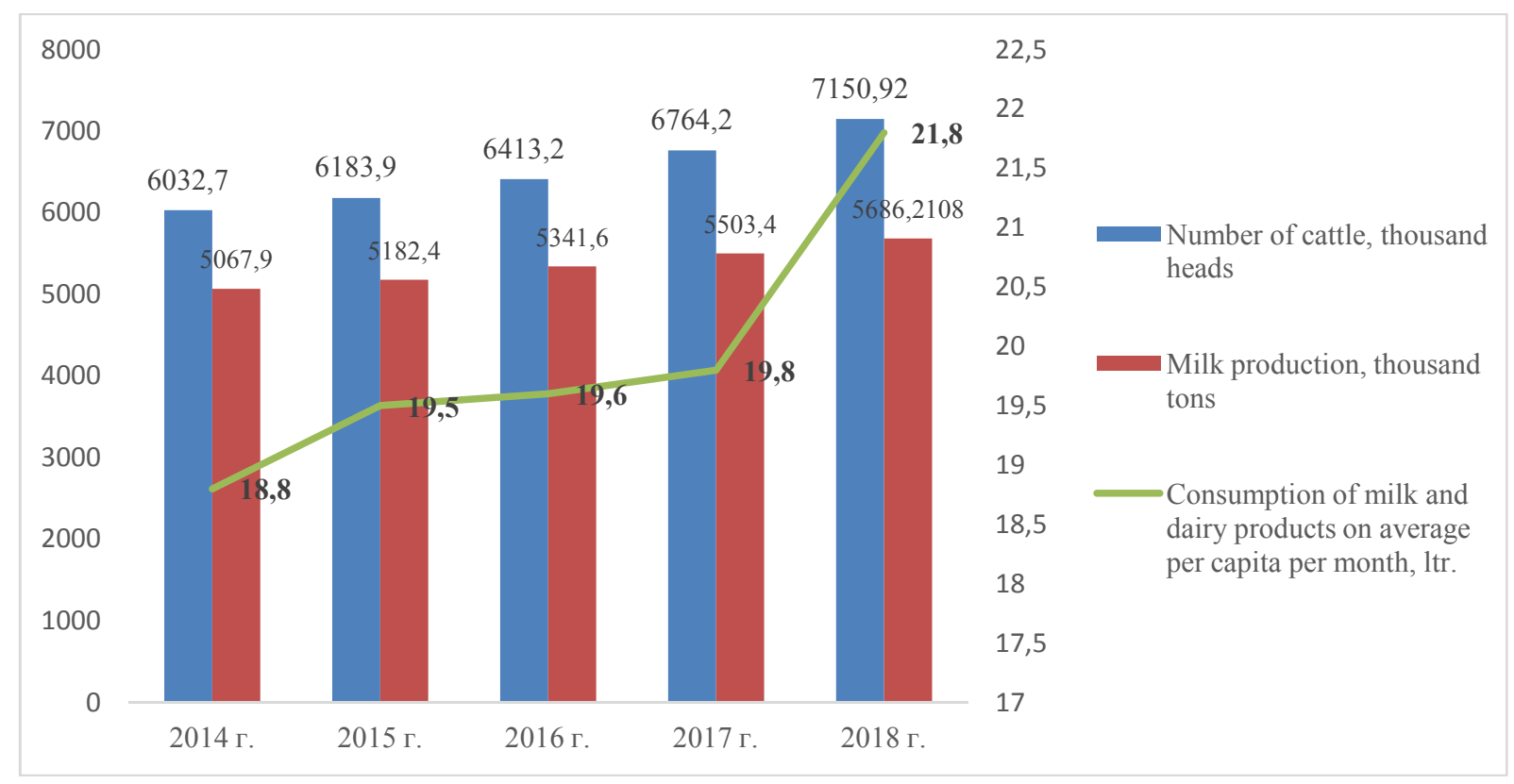

Figure 2. Key Dairy Industry Indicators of the Republic of Kazakhstan, 2014-2018

Note - compiled by the authors based on the data of the Committee on Statistics of the Republic of Kazakhstan.

Milk production is seasonal, but there is a demand for milk throughout the year, which causes fluctuations in procurement prices. The price of milk remains almost the only lever to influence the development, or vice versa, the curtailment of this type of business. However, while large enterprises can compete even with low purchase prices due to the scale of production and diversified nature of the economic activity, small peasant farms of the population suffer most from its fluctuations. In Kazakhstan, in 2018 the region produced 5,686.2 thousand tonnes of milk. At the same time, the bulk of raw milk was produced in private subsidiary farms of the population and by individual entrepreneurs and peasant (farm) farms. This fact testifies to the small commodity of dairy cattle breeding of the republic. The majority of experts and market analysts believe that one of the reasons for the persistence of negative trends in the milk market is a significant price fluctuation and their inconsistency with the costs that the producer spends on the maintenance of dairy herd. 


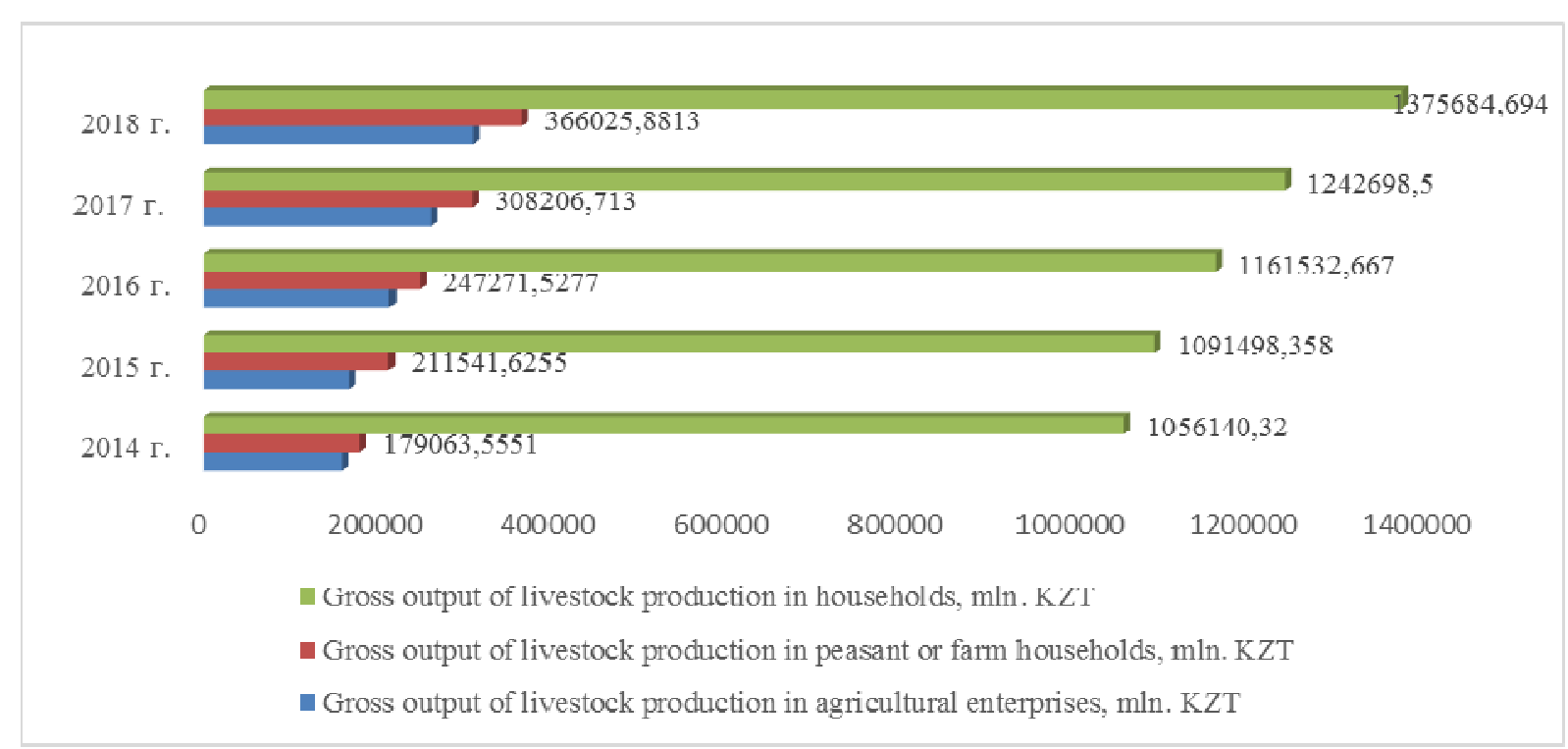

Figure 3. Gross output of livestock production by categories of farms, mln. KZT

Note - compiled by the authors based on the data of the Committee on Statistics of the Republic of Kazakhstan.

The main reasons for the high purchase prices of milk in Kazakhstan are its high cost and low productivity in the industry. Besides, the unfavorable situation is exacerbated by trade and intermediary structures, through which up to $30 \%$ of the dairy market goes.

In the current conditions of Kazakhstan's gradual progress towards achieving its main strategic goal the integration of the national economy into the system of world foreign economic relations - the problem of effective development of individual industries and regions of the country, as well as ensuring the competitiveness of domestic products in both domestic and foreign markets is extremely urgent. It is known that the quality of milk also determines the quality of processed products. Poor quality of dairy raw materials in the country and, as a result, dairy products significantly narrows down its markets, especially concerning exports. Given the current quality of domestic raw materials, the main consumer of domestic dairy products is the country's population.

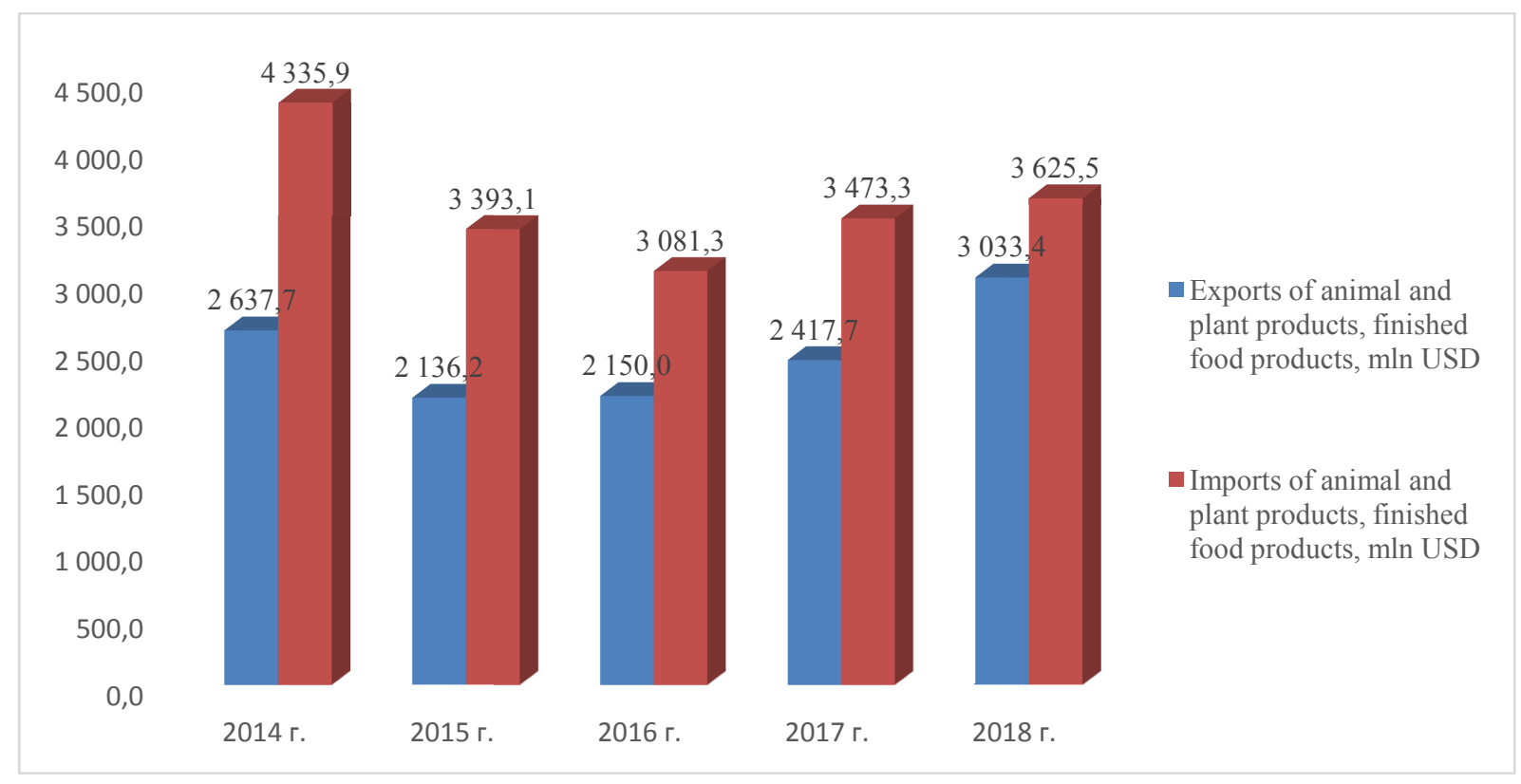

Figure 4. Volume of export and import of animal and plant products, mln. USD

Note - compiled by the authors based on the data of the Committee on Statistics of the Republic of Kazakhstan. 
Thus, the sales volumes of domestic producers of dairy raw materials of own production in all directions and its import provided a solvent market of dairy products for the country's population and the corresponding export potential.

A method of regression analysis was used to determine factors affecting the production of milk and dairy products. Regression analysis shows relationships between variables that could be defined as causation. A variable whose variations need to be explained or predicted is referred to as dependent variables. The purpose of regression analysis is to determine how and to what extent dependent variables change or change as a result of a change in a fixed variable (MacDonald et al., 2007; Ackerberg et al., 2015). Correlation analysis tests the interdependency and regression analysis of causal effects among more than two variables. More than one variable can be assumed to be independent and assess their effect on only one dependent variable. The nature of statistical information allowed using a linear model of multiple regression. Data for 2004-2018 were taken for analysis from the official website of the Committee on Statistics of the Republic of Kazakhstan. As an independent variable, we will consider the volume of milk and dairy products and the factors affecting milk and dairy products that were originally selected: raw milk price index for the previous year; share of rural population ; investment in agricultural fixed capital; milk production per capita; gross agricultural output (services); food retail volume; cattle stock; milk yield per cow. But, at the construction of the multiple regression equation the problem of multicollinearity of factors has arisen (André et al, 2007). After exclusion of the multicollinearity between the selected factors, the method of stepwise regression analysis remains as follows:

- capital investments (foxassinvest);

- food retailing volume (retailvol);

- share of rural population (agrshare).

A description of the factors under consideration is provided in table 1.

Table 1. Descriptive Statistics

\begin{tabular}{lrrrrr}
\hline Variable & Obs & Mean & Std.Dev. & Min & Max \\
\hline year & 15 & 2011 & 4.472 & 2004 & 2018 \\
milkprod & 15 & 5132.281 & 298.133 & 4556.8 & 5686.211 \\
foxassinvest & 15 & 5450000 & 2550000 & 1700000 & $1.12 \mathrm{e}+07$ \\
retailvol & 15 & 1210000 & 706000 & 370000 & 2690000 \\
agrshare & 15 & 44.142 & 1.491 & 42.118 & 46.916 \\
rawmikpric $\sim$ d & 15 & 109.193 & 7.698 & 97.8 & 127.7 \\
& & & & & \\
\hline
\end{tabular}

Note - calculated by the authors on the basis of data from the Committee on Statistics of the Republic of Kazakhstan.

The following statistical parameters were calculated for each variable: mean value, median, dispersion, standard deviation, minimum and maximum values according to the formulas. As a result, we can say that the average milk production volume is 5132.8 thousand tons. The rural population of 44.1 is the share of the rural population in the total number of the country's population, with an average of $44.1 \%$.

To quantitatively estimate the relationship between the variables and to construct a model of the relationship between the factors, we will construct a regression model based on the following formula:

$$
\operatorname{Milkprod}_{t}=\beta_{0}+\beta_{1} \text { foxassinvest }+\beta_{2} \text { retailvol }+\beta_{3} \text { agrshare }+\varepsilon_{t}
$$

Where:

- Milkprod - the production of milk and dairy products;

$-\mathrm{t}$ - years from 2004 to 2018

$-\beta 0$ - i-factor assessment;

$-\varepsilon_{\mathrm{t}}-$ other factors not taken into account.

The method of least squares is used to construct the multiple regression equation. As a result of the least squares method estimation, the data presented in Table 2 are obtained. 
Table 2. Results of regression to all variables

Linear Regression

\begin{tabular}{lrrrrrrr}
\hline milkprod & Coef. & St.Err. & t-value & p-value & {$[95 \%$ Conf } & Interval] & Sig \\
\hline foxassinvest & 0.002 & 0.000 & 3.33 & 0.008 & 0.000 & 0.001 & $* * *$ \\
retailvol & -0.001 & 0.000 & -2.56 & 0.029 & -0.002 & 0.000 & $* *$ \\
agrshare & -19.205 & 32.288 & -0.59 & 0.565 & -91.147 & 52.736 \\
rawmikpriceind & 4.920 & 6.146 & 0.80 & 0.442 & -8.774 & 18.615 & $* 28.965$ \\
Constant & 4609.404 & 1444.955 & 3.19 & 0.010 & 1389.844 & 7828 \\
Mean dependent var & & 5132.281 & SD dependent var & & 298.133 \\
R-squared & 0.808 & Number of obs & 15.000 & 0.001 \\
F-test & 10.548 & Prob $>$ F & 201.215
\end{tabular}

$* * * p<0.01, * * p<0.05, * p<0.1$

Note - complied by the author in the statistical batch program STATA on the basis of data from the Committee on Statistics of the Republic of Kazakhstan

Regression coefficient $\mathrm{R}^{2}-0,808 ; \mathrm{P}$-value $=0,000 ;$ F-criterion Fisher-10,548. According to the obtained results, with $80.8 \%$ probability, it can be stated that the model is reliable, the connection is statistically confirmed.

\section{Discussion}

We have calculated the factors affecting milk and dairy production using regression analysis using the example of the dairy industry of the Republic of Kazakhstan. The conducted regression analysis showed that investment in fixed assets has a positive impact on the performance of this industry and is statistically significant. The availability of sufficient investments is a necessary condition for the effective and sustainable development of any sector of the national economy Agriculture, including the dairy sector of the country is no exception, although the sector remains a little attractive to the majority of investors. Therefore, the research on the improvement of mechanisms of attraction of investments into the agrarian sector of economy and methods of increase of investment attractiveness of agriculture for maintenance of its sustainable economic development and improvement of industrial activity of enterprises becomes especially urgent. The volume of retail trade in food products hurts milk and dairy production. In our case, we have taken the data for the whole retail trade and the share of milk and dairy products in this turnover is very small. The results obtained can be used to study the influence of factors on the dairy enterprise production activities at any level and different ownership forms.

\section{Conclusion}

Studies have shown that the functioning of the milk and milk products market depends on market infrastructure, quality raw material base, production status and the solvency of consumers. The problems of the pricing of agricultural producers of milk have become much more complicated in recent years.

Milk production in Kazakhstan can become a profitable, competitive kind of agribusiness, but this process is long and requires significant investments in equipment for optimized feeding of animals, modernization and renewal of milking systems, reconstruction of farm premises, purchase of breed composition of a dairy herd. According to calculations, the profitability of dairy production is $7-9 \%$, this indicator is low among the total mass of agricultural enterprises. In this situation, the government's assistance is extremely necessary. Firstly, it concerns ensuring an acceptable tax regime for livestock development. Secondly, the support of subsidies to the feed base, which will have a positive impact on the dairy sector in the future. We believe that these ways will allow us to accumulate money for the development of the technical base of dairy processing enterprises and improve the quality of products. All this is relevant, because, as noted earlier, the dairy industry is a strategically important sector of the country.

\section{Acknowledgment}

I am grateful to all the scientific advisors who provided me with extensive personal and professional guidance, which taught me a lot about research and life in general. I also would like to thank my parents, whose love and guidance is with me in what I pursue.

\section{References}

Alwis, A., Edirisinghe, J. \& Athauda, A. (2009). Analysis of Factors Affecting Fresh Milk Consumption Among the Mid-Country Consumers. Tropical Agricultural Research and Extension, 12(2), 103-109. 
André, G., Berentsen, P., Van Duinkerken, G., Engel, B. \& Lansink, A. (2010). Economic potential of individual variation in milk yield response to concentrate intake of dairy cows. The Journal of Agricultural Science, 148(3), 263276. doi:10.1017/S0021859610000134

Ackerberg, D. A., Caves, K. \& Frazer, G. (2015). Identification properties of recent production function estimators. Econometrica, 83 (6), 2411-2451.

Dairy Council of California. (2015). Milk Myth Busters [online]. http://www.healthyeating.org/Milk-Dairy/Milk-MythBusters.aspx.

Dallmeier, L. (2012). Milk-Natural Beauty throughout History [online]. http://www.herbhedgerow.co.uk/milk-naturalbeautythroughout-history/.

David, I., Robert, G., Matthew, W., Christina, L., Stephen, J. \& Martina J. (2013) The Dairy Industry: A Brief Description of Production Practices, Trends, and Farm Characteristics Around the World. Journal of Agromedicine, 18:3, 187-197. doi: 10.1080/1059924X.2013.796901.

Furindová, N. (2010). Význam a spotreba mlieka a mliepnych výrobkov. In: Instore Slovakia.

Khassenova, K.K., Shamisheva, N.K., Issayeva, B.K. \& Niyazbekova, Zh.U. (2020). The investment climate of the regions of Kazakhstan: issues of state regulation. Bulletin of the Karaganda University. Economy series, 1(97), 3950.

Krešiü, G. Herceg, Z., Lelas, V. \& Režek Jambrak, A. (2010). Consumers' Behaviour and Motives for Selection of Dairy Beverages in Kvarner Region: a Pilot Study. Mliekajstvo. 60(1), 50-58.

MacDonald, J., O’Donoghue, E., McBride, W., Nehring, R., Sandretto, C. \& Mosheim, R. (2007). Profits, Costs and the Changing Structure of Dairy Farming. Economic Research Service, 47, 8-14. http://ageconsearch.umn.edu/record/6704/files/er070047.

Nguyen, Hien. (2016). Competitive analysis of Vietnam dairy industry. Science and Technology Development Journal, 19, 48-67. doi: 10.32508/stdj.v19i4.771

OECD/FAO (2019), OECD Agriculture statistics (database), http://dx.doi.org/10.1787/agr-outl-data-en.

Taipov, T.A. (2018). Public support models of agricultural production in the EAEU countries. Bulletin of the Karaganda University. Economy series, 2(90), 91-99.

The Dairy Council, 2014. Macro-nutrients in Milk . http://www.milk.co.uk/page.aspx?intPageID=70.

The National Dairy Council, (2008). Dairy: Food for Life. A Strategy to Promote Irish Milk \& Dairy Products 20082012 [online]. http://www.ndc.ie/docs/ndc-strategy-report.pdf.

\section{А.Ж. Байгужинова, Л. Тылл}

\section{Қазақстан Республикасы бойынша сүт өндірісінің дамуын экономикалық және статистикалық талдау}

\section{Аңдатпа}

Maқ̧cambl: Қазіргі бәсекелестік жағдайдағы Қазақстандағы сүт және сүт өнімдерін өндіруге әсер ететін негізгі факторларды зерттеу.

Әдісі: Мақалада сандық мәліметтер және байланыстарды зерттеу үшін математика-статистикалық әдістер қолданылған (корреляция-регрессиялық талдау).

Kорытылды: Зерттеу Қазақстандағы сүт өндірісі және оның ерекшеліктеріне арналған. Біз Қазақстан Республикасының сүт саласы мәліметтері негізінде, сүт және сүт өнімдерін өндіруге әсер ететін факторларды регрессиялық талдауды қолдана отырып есептедік. Регрессиялық талдау көрсеткендей, негізгі капиталға салынған инвестициялар осы саланың жұмысына оң әсер етеді және статистикалық маңызды. Алынған нәтижелер кез-келген деңгейдегі және әртүрлі меншік нысандарындағы сүт кәсіпорнының өндірістік қызметіне факторлардың әсерін зерттеу үшін қолданыла алады.

Тұжырымдама: Қазақстанның сүт өндірісіне әсер ететін негізгі факторлар зерттелген. Сүт өнеркәсібінің даму деңгейін арттыру үшін бірінші кезектегі қажетті шаралар ұсынылған.

Кілт сөздер: сүт өнеркәсібі, сүт және сүт өнімдері, сүт саласының даму қарқыны мен болашағы.

\section{А.Ж. Байгужинова, Л. Тылл}

\section{Экономико-статистический анализ развития молочной отрасли Республики Казахстан}

\footnotetext{
Аннотация

Цель: Изучение основных факторов, влияющих на производство молока и молочных продуктов Казахстана в нынешних условиях конкуренции.

Memoдb: В статье используются количественные данные, математико-статистические методы изучения связей (корреляционно-регрессионный анализ).

Результаты: Данное исследование посвящено молочной отрасли Казахстана и ее особенностям. Нами были рассчитаны факторы, влияющие на производство молока и молочной продукции, с помощью регрессион-
} 
ного анализа на примере молочной отрасли Республики Казахстан. Проведенный регрессионный анализ показал, что инвестиции в основной капитал положительно влияют на результаты деятельности данной отрасли и статистически значимы. Полученные результаты могут быть использованы для изучения влияния факторов на производственную деятельность молочных предприятий любого уровня и разной формы собственности.

Bblвoдbl: Изучены основные факторы, влияющие на молочную отрасль Казахстана. Предложены приоритетные меры по повышению уровня развития молочной промышленности.

Ключевые слова: молочная отрасль, молоко и молочная продукция, тенденции и перспективы молочной отрасли.

\section{References}

Alwis, A. Analysis of Factors Affecting Fresh Milk Consumption Among the Mid-Country Consumers [text] / J. Edirisinghe, A. Athauda // Tropical Agricultural Research and Extension. — 2009. — № 12(2). — P. $103-109$.

André, G. Economic potential of individual variation in milk yield response to concentrate intake of dairy cows [text] / P. Berentsen, G. Van Duinkerken, B. Engel \& A. Lansink // The Journal of Agricultural Science. — 2010. — № 148(3). — P. 263-276. doi:10.1017/S0021859610000134

Ackerberg, D.A. Identification properties of recent production function estimators [text] / K. Caves, G. Frazer// Econometrica. — 2015. - № 83(6). - P. 2411-2451.

Dairy Council of California. Milk Myth Busters — 2015. [online]. Available at: www.healthyeating.org/MilkDairy/Milk-Myth-Busters.aspx.

Dallmeier, L. Milk-Natural Beauty throughout History — 2012. [online]. Available at: www.herbhedgerow.co.uk/milknatural-beautythroughout-history/.

David, I. The Dairy Industry: A Brief Description of Production Practices, Trends and Farm Characteristics Around the World [text] / G. Robert, W. Matthew, L. Christina, J. Stephen, J. Martina // Journal of Agromedicine. — 2013. № 18:3. - P. 187-197. doi: 10.1080/1059924X.2013.796901

Furindová N. Význam a spotreba mlieka a mliepnych výrobkov / N. Furindová. In: Instore Slovakia-2010. September.

Khassenova, K.K. The investment climate of the regions of Kazakhstan: issues of state regulation [text] / N.K. Shamisheva, B.K. Issayeva, Zh.U. Niyazbekova // Bulletin of the Karaganda University. Economy series. — 2020. — № 1(97). - P. 39-50.

Krešiü, G. Consumers' Behaviour and Motives for Selection of Dairy Beverages in Kvarner Region: a Pilot Study [text] / Z. Herceg, V. Lelas, A. Režek Jambrak // Mliekajstvo. — 2010. — № 60(1). — P. 50-58.

MacDonald, J. Profits, Costs and the Changing Structure of Dairy Farming [text] / E.O'Donoghue, W. McBride, R. Nehring, C. Sandretto, R. Mosheim // Economic Research Service. — 2007. — № 47. - P. 8-14. http://ageconsearch.umn.edu/record/6704/files/er070047.

Nguyen. Hien Competitive analysis of Vietnam dairy industry [text] // Science and Technology Development Journal. — 2016. — № 19. — P. 48-67. DOI: 10.32508/stdj.v19i4.771

OECD/FAO, OECD Agriculture statistics (database), http://dx.doi.org/10.1787/agr-outl-data-en.

Taipov T.A. Public support models of agricultural production in the EAEU countries[text] / T.A. Taipov // Bulletin of the Karaganda University. Economy series. — 2018. — № 2(90). — P. 91-99.

The Dairy Council, Macro-nutrients in Milk -2014. [online]. Available at: www.milk.co.uk/page.aspx?intPageID=70.

The National Dairy Council. Dairy: Food for Life. A Strategy to Promote Irish Milk \& Dairy Products 2008-2012 [online]. Available at: www.ndc.ie/docs/ndc-strategy-report.pdf. 